\title{
APPLYING A LESSON PLAN FOR A DIGITAL CLASSROOM: CHALLENGES AND BENEFITS
}

\author{
Ahmad Sugianto \\ Universitas Pendidikan Indonesia \\ ahmadsugianto@upi.edu
}

\begin{abstract}
A lesson plan is one of the essential parts that may lead English teachers to gain the expected learning outcome. Nevertheless, to implement the lesson plan so that the expected outcome can be met might be challenging if conducted in a digital classroom. This study was aimed to unravel the way a lesson plan was implemented in a digital classroom. A case study was employed and the collected data from interview, classroom observation, and document were analysed through an interactive model. Findings revealed that both strength and weakness as a result of implementing the lesson plan for a digital classroom were perceived by the subjects. This study reached a conclusion that the lesson plan was categorised as good, i.e. it conforms $86.9 \%$ to the components of the curriculum 2013. Moreover, the challenges consisted of the aspects of the network connection, preparation, and students' familiarity with the use of the technology; meanwhile, the benefits covered the aspects of the resources, students' skills and participation, and efficiency.
\end{abstract}

Keywords: curriculum 2013, digital classroom, lesson plan

\section{INTRODUCTION}

A lesson plan is one of the essential components that English teachers require to take into account. It is used as a guide line through which the teachers' instructions lead to the expected outcome. Furthermore, the instruction process conducted by them are embedded in it comprising the objectives, topics, materials, time allotment, level, type of the used method, activities, and the way the assessment is conducted (Brown, 2001; Nesari and Heidari, 2014; Permendikbud No. 65, 2013).

Moreover, studying a lesson plan is important due to the fact that the way teachers construct and deliver their instruction is included in a lesson plan. According to the Teaching Excellence in Adult Literacy (TEAL) Center (2010), a lesson plan is a planning tool which is considered as a detailed description of a teacher's instruction of a lesson through which the learning objectives can be attained by learners; also, it covers the explanations related to the lessons and the assessments, contents, materials, time, instructional strategies, and assistance strategies in the classroom. From this notion, the key issue related to the definition of a lesson plan is that a lesson plan is associated with a tool used to achieve a particular objective created and employed by teachers.

Moreover, Richards and Bohlke (2011) point out that a lesson plan constitutes the decision that teachers have made; this are reflected into goals, activities, sequencing or the order of the ways a classroom is employed, such as opening and closing, the spent time (timing) for different activities, grouping (if the class will be taught as unity and students will work in pairs or group, and resources or the materials will be employed such as textbook, worksheet, and DVDs. Based on the notions advocated by Richards and Bohlke and TEAL above, a lesson plan is considered helpful and useful to make the learning and teaching process runs as it is supposed to be or in line with the goal; nevertheless, in Richard's and Bohlke' notions, there is no an emphasis or at least explicitly it mentions that in a lesson plan there should be an assessment included.

Furthermore, Department of Education of Tasmania Government (2014) brings up that a lesson plan is a description about the lesson that will be taught and the assessment in a certain time; besides, a lesson plan is considered to have an association to the pedagogy and curriculum as well as the student's needs; also, a lesson plan has to do with the specific phases of a lesson comprising: 1) the introduction refers to the activity in which new concepts are introduced, 
VOL. 02 NO. 02, DECEMBER 2020

previous learning is reviewed and prior knowledge is activated; 2) the explicit teaching teaching/guided action refers to the activity where students work in group or individually to cope with the problem or task given and particular strategies and skills are demonstrated and modelled by teachers which then the responsibility is given to the students; 3 ) the review refers to the activity in which the assessment is conducted; it is useful to help teachers in planning the next instructions.

Meanwhile, a similar definition is stated by the regulation of the Ministry of Education and Culture No.22 year of 2016, chapter III, point 2; however, based on this regulation, a number of new terms are proposed and introduced such as basic competence as well as a more detail elaboration of the objectives of a lesson plan in the instruction is given; it specifically states that a lesson plan (Rencana Pelaksanaan Pembelajaran/RPP) is defined as the plan of the learning activities for one or more meeting; it is developed from the syllabus to direct the students' learning activities to achieve the basic competence; every teacher is required to make a lesson plan completely and systematically in order that the learning taking place can be interactive, inspiring, fun, challenging, efficient, motivating students to actively participate in the learning and giving a space for students' work, creativity, and independence in accordance with their passion, talent and psychological and physical development.

By having the lesson plan, teachers and students are expected to get benefits from it, such as the learning process that is fun, inspiring, efficient, motivating, challenging, interactive and so forth. However, despite its importance, a lesson plan is required to be designed and implemented carefully so that the outcomes expected can be obtained. In this case, it should be in line with the curriculum prevailed, i.e. Curriculum 2013. Besides, the recent condition is even more challenging since teachers are expected to adapt the instruction by making use of the technology. This condition is as a result of the current trend of Industry Revolution (IR) 4.0 in which everything is associated with digitalization and automation. As Kusmin, Hariharasudan and Kot (2018) asserts that IR 4.0 will take influences towards the whole human's contexts of life. In addition, as a result of the emergence of the trend of IR 4.0, transformation related to the education model is taken into account; this turns out to education 4.0 in which classroom and the way the instructions are computerized (Sharoom and Hussin, 2018).

In the education 4.0., the use of technology cannot be neglected in delivering the instructions. This based-use of technology or digital learning is expected not to be a burden for teachers and students, but on the other hand it tries to aid the learning and teaching process to be more effective. Daggett (2004) points out that the use of digital learning can accelerate the students' experiences towards the learning associated with their literate in terms of technology that will be useful for their future career.

According to the Ministry of Education and Culture a digital classroom is defined as: Learning Management System (LMS) yang dikembangkan khusus untuk memfasilitasi proses pembelajaran virtual atau tanpa tatap muka antara guru dan siswa. Dengan fitur ini, guru dapat memberikan bahan ajar yang dapat diakses dan dibagikan oleh siswa dalam bentuk digital kapan saja dan di mana saja. (a Learning Management System (LMS) which is developed to facilitate the learning process in a virtual form; through this feature teachers may share a number of resources that can be accessed by the students in everywhere and everytime.) (Portal Rumah Belajar, 2019).

In addition, Munir (2017) points out that digital learning requires the learners as well as the teachers who can communicate interactively through using the information and communication technology, such as from a computer media with the internet, mobile phone with a number of its applications, video, and so on.

To connect the use of digital classroom in education 4.0, then it is necessary to identify the characteristics of education 4.0; in this case, Hussin (2018) asserts that there are nine characteristics portraying education 4.0:1) learning conducted is not tied or limited to time and 
VOL. 02 NO. 02, DECEMBER 2020

place; 2) personalised learning is given emphasis; 3) learning is based on the students' own choice; 4) project based learning is given the emphasis; 5) learning necessarily makes use of direct experience; 6) application of the concepts of the knowledge and reasoning is given emphasis; 7) differentiation in terms of the assessment; 8) involvement of students in designing and developing the curriculum is necessary; 9) student autonomy learning and the teachers' role as a facilitator is given emphasis. Moreover, the current education is required to accommodate and foster the current skills needed, i.e. 21st century skills and thus education 4.0 has necessarily to do with the skills as well. Bialik and Fadel (2015) point out the four 21st century skills needed encompass creativity, critical thinking, communication, and collaboration. Based on the views above, learning in a digital classroom in education 4.0 can be synthesised as the learning conducted by making use of a number of hardware and software such as mobile phones, computers, applications, the internet, which can be conducted anywhere and anytime, as well as the students' involvement and the 21 st century skills are necessarily given the emphasis.

Due to the important use of digital learning, the schools are required to make a relevant breakthrough. One of the instances that may accommodate this is employing a classroom which is digitalized or digital class. Besides, Aminah (2015) reported that Bandung had been developing a digital classroom gradually; additionally, she asserted that the digital classroom facilitated the students' learning which is systematically computerised through making use of a number of devices, such as tablets or computers and so forth.

Based on the rationale above, this study is aimed to unravel the way an English teacher implement the lesson plan for a digital classroom; specifically it attempts to reveal the challenges and opportunities encountered during the implementation of the lesson plan in the digital classroom.

\section{METHOD}

A qualitative research was employed in this study. In addition, a case study was used since this study attempted to describe and have more in-depth understanding of a case, i.e., the way a lesson plan is designed and implemented in a digital classroom, in a particular setting, i.e., at one of the public schools in Bandung city.

\section{Respondents}

The subjects involved in this study were determined through a purposive sampling technique. In this case, the subjects comprised a female English teacher and six students (consisting of three female students and three male students) at one of the public schools in Bandung city. The subjects were chosen based on some considerations. First, the availability of a digital classroom for the English instruction at the school, and the female English teacher was the one who utilised it (this information was gained through a preliminary study conducted through observing the classroom on October 15 2019); Second, the researcher had accepted their consent to be involved in this study by filling in and signing the research consent letter or form given.

\section{Instruments}

In this study, a number of instruments were used, i.e. interview, classroom observation, and document. The explanations of each instrument are explained as follows:

\section{Interview}

A semi-unstructured interview categorized as an in-depth interview was employed. This type of interview was chosen based upon a ground, namely to get deeper and more comprehensive data. This type of interview is not only considered beneficial for the researchers but also the subjects since the subjects can be more involved because they feel more comfortable to participate in the research; this condition are expected to enable them to convey more and 
VOL. 02 NO. 02, DECEMBER 2020

deeper about what their views of the research matter which may eventually lead to the more comprehensive findings. A number of interview guidelines which comprised a number of lists of question items related to the research matter being investigated were systematically prepared. There were 30 items addressed to the teacher and 15 items addressed to the students. To avoid language barrier and misunderstanding of the meaning, all the items were translated into Bahasa Indonesia during the interviews were conducted.

\section{Classroom observation}

A classroom observation was employed as a companion and confirmation of the other research instruments. It was used to see the real condition in which the lesson plan was implemented. In addition, the non-participant observation was employed in this study. In this case, the researcher was not directly involved in the situation or activity observed. He only watched the English teaching and learning process conducted in the classroom. In this study, a classroom observation form developed by Department of English, City University of Hong Kong (Richards, 2001) were used (see Appendix 6).

\section{Document}

It constitutes the document taken from the school. It was the lesson plan made and implemented by the English teacher. The lesson plan was used to see whether or not its components had conformity with the regulations of the Ministry of Education and Culture No. 22 year of 2016 as well as to see whether or not the contents of the lesson plan had conformity with the real teaching and learning process conducted in the classroom.

\section{Procedures}

There were a number of procedures in collecting data of this study. First, after the subjects signed the consent to participate in this study, the researcher conducted the interview with them. He interviewed them based on the interview guidelines prepared and formulated. Also, he audio-taped the interview conducted with the subjects. The results of the interviews which were in the forms of audio were then transcribed to be analysed together with the other research instruments. Second, he also copied the lesson plan that would be implemented in the classroom; he learned and analysed it based on the checklist provided (see Appendix 7). Third, the researcher conducted a classroom observation. He observed the classroom in which the lesson plan was employed.

\section{Data analysis}

The data of this study were analyzed by using interactive model encompassing three concurrent flows of activity (data reduction, data display, and conclusion drawing/verifying) advocated by Miles and Huberman (1994) comprising: 1) data collection and reduction, i.e. the researcher tried to collect the data from the three instruments, i.e., the interview, document in the form of a lesson plan, and classroom observation; then, these were simplified and transformed as well as transcribed. In addition, the process of data reduction was conducted by the researcher as long as he piloted the research project; 2) data display, i.e. in this regard, the data gained from the interview, classroom observation, and document in the form of a lesson plan are described in details in the form of extended texts; 3 ) conclusion drawing/verifying, i.e. in this case, the researcher tried to determine the meaning of the data gained from the three instruments, i.e., the interview, classroom observation, and document in the form of a lesson plan. This stage was conducted even as the data collection was started and it ended as it was perceived that the final conclusion had been obtained.

\section{FINDINGS AND DISCUSSION \\ Result of the Document Analysis}


VOL. 02 NO. 02, DECEMBER 2020

Based on the analysis conducted to the lesson plan, there were 10 items or components on the lesson plan. Those ten components were suitable and similar to what had been mentioned in the regulation of the Ministry of Culture and Education No. 22 year of 2016, which comprised the school identity, lesson identity or theme/subtheme, class/semester, main material, time allocation, the learning objective, basic competence and indicator of the competence achievement, learning materials, learning method, learning media, resource, learning steps, and the learning assessment as well as the enrichment and remedy program included.

In addition, based on the analysis form of the lesson plan which score range starts from 1 to 3 with criteria 'absent or not suitable' for 1, 'less complete or partly suitable' for 2 and 'already complete or all suitable' for 3, the detail results of the analysis are as follows. First, in terms of the component of the identity of the lesson plan, the lesson plan had met the standards in accordance with the regulation of the Ministry of Education and Culture No. 22 Year of 2016. In this case, in this component, the lesson plan included the school subject, class/semester, theme/subtheme, time allocation. Therefore, in terms of this component, the researcher gave 3 for this component with criteria 'already complete'.

Second, in terms of the component of the core competence and basic competence, the lesson plan had met the standards in accordance with the regulation of the Ministry of Education and Culture No. 22 Year of 2016. In this case, in this component, the lesson plan had covered the two components, core competence and basic competence. Therefore, in terms of this component, the researcher gave 3 for this component with criteria 'all suitable'.

Third, in terms of the formulation of the indicator, the lesson plan had met the standards in accordance with the regulation of the Ministry of Education and Culture No. 22 Year of 2016. In this case, in this component, the indicators of the lesson plan had already been developed in line with the basic competence, the operational verb used with the competence that will be measured, knowledge aspect, and skill aspect. Therefore, in terms of this component, the researcher gave 3 for this component with criteria 'all suitable'.

Fourth, in terms of the formulation of the learning objective, the lesson plan had been developed appropriately based on the basic competence, indicator, as well as the aspects of audience, behaviour, condition, and degree. Therefore, in terms of this component, the researcher gave 3 for this component with criteria 'all suitable'.

Fifth, in terms of the material selection, the lesson plan had been developed in line with the basic competence, learning objectives, learner's characteristics, and the order of the learning materials. Therefore, in terms of this component, the researcher gave 3 for this component with criteria 'all suitable'.

Sixth, in terms of the resources, the lesson plan had been developed in line with the basic competence, learning objectives, learning materials, scientific approach, and learner's characteristics. Therefore, in terms of this component, the researcher gave 3 for this component with criteria 'already complete'. However, there is a note given here, i.e., the textbook used still was still the older version, i.e., 2014 edition not the latest revised, i.e. 2017 edition.

Seventh, in terms of the learning media selection, the lesson plan had been developed in line with the basic competence, learning objectives, learning materials, scientific approach, and learner's characteristics. Therefore, in terms of this component, the researcher gave 3 for this component with criteria 'all suitable'.

Eighth, in terms of the learning model used, the lesson plan was in conformity with the learning objectives and the characteristics of the materials. Therefore, in terms of this component, the researcher gave 3 for this component with criteria 'all suitable'.

Ninth, in terms of the learning method used, the lesson plan was in conformity with the learning objectives and the characteristics of the materials, as well as the learner's characteristics. Therefore, in terms of this component, the researcher gave 3 for this component with criteria 'all suitable'. 
Tenth, in terms of the learning scenario or steps, the lesson plan had presented the three steps in the scenario clearly comprising the introduction, core, and closure; also, it was in conformity with scientific approach comprising observing, questioning, collecting information, associating, and communicating; besides, it was in line with the learning method, and there was a conformity between the activity and the material order. Therefore, in terms of this component, the researcher gave 3 for this component with criteria 'already complete', particularly for those aspects above; however, in terms of the conformity between the time allocation and the three stages of learning, i.e. introduction, core, and closure, the lesson plan obtained 2 since on the first meeting, the allocation time for the introduction and core activities did not include or mention the time.

At last, in terms of the design of the learning assessment, the lesson plan gained 2 ('partly suitable') on average in terms of the following: the conformity between the form, technique and instrument with the indicator of the achieved competence, the conformity between the form, technique and instrument with affective assessment, the conformity between the form, technique and instrument with the cognitive (knowledge) assessment, the conformity between the form, technique and instrument with skill assessment. It was due to the fact that the assessment instruments were not included or enclosed and the scoring scales were not in range 00 to 100 . The total score for the fulfilment of the components were 103 out of 115 or equals to 89.6 in percentage which was categorized as Good.

\section{Result of Interview with the Teacher}

Based on the transcript of the interview with the teacher, the study found that: The teacher had adequate knowledge in relation to the current trend of industry 4.0., which can be indicated by her response that stated that it entails the education in $21^{\text {st }}$ century skills which encompass collaboration, critical thinking, communication, and creativity. In detail, she mentioned:

Kalau untuk pendidikan kan kita sudah mengacu pendidikan abad 21. 4.0 itu ya semacam karena pendidikan di abad 21 itu mencakup empat hal yaitu, collaboration, critical thinking, ee.. communication, and creativity. (for our education, it has actually refered to education for education which is the same as education 4.0 because it accommodates the $21^{\text {st }}$ century skills, namely collaboration, critical thinking, ee.. communication, and creativity.) (T, interview on 25 October 2019).

Furthermore, her understanding is not only in the domain of theories but also, in the domain of practice. It can be indicated by the way, her understanding of the concept of the current trend was required to be manifested in students' learning. The students were given the opportunities to have more creativity, make innovation, and do explorations instead of being merely spoon-fed by her through listening her explanation in the classroom. In details, she mentioned:

Memberikan ruang bagi siswa untuk lebih kreatif, lebih inovatif, dan lebih memberikan kesempatan kepada anak-anak untuk berekplorasi dibandingkan hanya harus mendengarkan gurunya di depan kelas saja (providing a space for students to be more creative, innovative and also giving them an opportunity to explore instead of only hearing their teacher's explanation in front of the class.) ( $\mathrm{T}$, interview on 25 October 2019)

There were a number of facilities that the teachers used. They comprised several platforms such as Web-Blog, Quipper, Quizizz, Google Classroom, and Generation Global. Besides, there were not any meaningful matters to deliver or employ those kinds of applications or programs since according to her a number of trainings were provided.

In terms of the lesson plan, the teacher had good understanding of the concepts of how to design a lesson plan in terms of several aspects or components that constructed it, such as started from the core competence, basic competence, and the indicators of the achieved 
competence. Also, she mentioned that the regulation of the Ministry of Education and Culture related to designing a lesson plan comprising the Regulation of the Ministry No. 20, 21, 22, 23, and 24 as well as the latest one was about core competence and basic competence in the Regulation No. 37 year of 2018. In detail, she mentioned:

Guideline itu intinya sesuai dengan permen. Nomor berapa ya, pokoknya 20, 21, 22, 23, 24. Dan yang terbaru itu kan KI KD no. 37 tahun 2018. Kalau 20,21,22,23,24 itu di standar proses itu tahun 2016 (The guideline is essentially in accordance with the Regulation of the Ministry. What numbers? It is essentially Numbers 20, 21, 22, 23, 24. And the latest one is $K I$ (Core competence) $K D$ (Basic competence) no. 37 year of 2018). (T, interview on 25 October 2019)

Besides, the materials included in the lesson plan were required in accordance with the syllabus prepared as well as these were required to conform to the students' ability. Also, the materials should be familiar or contextual with the students' life or era, for instance bringing the English songs that were not too old to the class, or through delivering the latest themes. In detail, she mentioned:

Sesuai dengan silabus. Disesuaikan dengan silabus yang ada, jadi nanti kita susun disesuaikan dengan kemampuan siswanya... Jadi misalnya kalau lagu jangan terlalu old banget lah, ... tapi tema-tema yang lagi booming saat ini. (In line with the syllabus. Fit to the existing syllabus, so we arrange it based on the students' ability... For example, when delivering a song, it should not be the too old song, ... but in line with the theme which is booming recently) (T, interview on 25 October 2019).

Moreover, according to her, a good lesson plan had some characteristics such as measurable, applicable, and it also depends on the teacher's ability to adapt it. Besides, some training related to designing a lesson plan were also given, for example through a meeting in MGMP (Musyawarah Guru Mata Pelajaran) or English Teacher Organisation.

Besides, the opportunities or possible benefits that might obtained in designing a lesson plan for a digital classroom was the abundant materials or resources that could be found. According to her, numerous resources from the internet could be searched and used. Besides, if the students had been already proficient in communicating through English, it was also possible to drive and introduce the students with the materials adopted from the Sustainable Development Goals from United Nations which discussed about particular topics such as geography, environment, or the issues related to nature, humans and their expectations. Thus, she asserted that it was relative easy to find out the materials. In detail, she mentioned:

Banyak, searching di internet, ... dari lingkup yang terdekat dulu, tentang dirinya dulu, kemudian keluarga, sekolah, teman, ... Baru setelah itu saya mengambil topik-topik dari Sustainable Development Goals yang dari United Nations, seperti tentang kebumian, lingkungan,... (Many, searching from the internet, ... from the closest aspect, about themselves first, then family, school, friends, ... after that, I took the topic from Sustainable Development Goals which are from United Nations). (T, interview on 25 October 2019).

In addition, the challenges found and perceived by the teacher in designing a lesson plan in this era was a teacher was required to equip and have much knowledge as much as possible to lead them to make a meaningful classroom which could explore all the students' capabilities and potential through using a number of medias that were challenging and made the students be motivated. In detail, she mentioned:

...kita dituntut untuk banyak tahu dan memaksimalkan hal yang kita punya,... untuk membuat meaningful classroom ... mengeksplorasi semua kemampuan dan potensi siswa lebih maksimal... (we are insisted on knowing more and maximise what we have,... to make a meaningful classroom... to explore all the students' capabilities and potentials more maximally). (T, interview on 25 October 2019). 
Furthermore, there were a number of possible benefits or opportunities that might be obtained as a result of digital classroom. For instance, from the Generation Global platform, not only the students could develop their writing skill but it also trained their critical thinking since they were required to know others' background; besides, it could introduce the students to know other cultures from other countries, to make a connection with them as well as appreciate others with appropriate manners, and build empathy or sympathy to others. Besides, the students might get and share new information or knowledge about other countries' cultures from the indigenous students and vice versa, e.g. they could know that in India there was a Dvali festival in comparison Lebaran in Indonesia through a video conference, and it might make them able to express their thoughts spontaneously.

Meanwhile, in terms of the implementation the digital classroom, a number of challenges were perceived by the teacher. For instance, the teacher was required to drive as well as drill the lower students to catch up with the materials learned. In detail she mentioned:

Kendalanya bagi saya adalah mendrill anak-anak yang dalam tanda kutip kemampuannya masih di bawah itu adalah kerja keras bagi saya (The obstacle for me is to drill the students whose capabilities were still lower, and it requires a hard work) ( $\mathrm{T}$, interview on 25 October 2019).

Besides, she perceived that the teachers' tasks were not easy; teachers were insisted on being able to be smart in designing a learning method, to be able to make the media that would be used in the class, and to be a proficient teacher who could make students understand the materials. In detail, she mentioned, “...Jadi sekarang itu ya guru diminta administrasinya harus bagus, mengajarnya harus keren, media yang dipakai juga harus wah. (... So, at the present time, teachers are required to have good administration, the way they teach should be cool; the media used should be 'wow')." (T, interview on 25 October 2019).

\section{Results of the interviews with students}

Based on the transcript of interview with the students, the study reached some conclusions: Some students felt that the use of digital classroom made more efficient and fun in learning English. For instance, they did not have to write, just click. In detail the students told:

Ya enak aja si, jadi kaya tadi kalau di kelas kita tidak perlu nulis panjang-panjang. Jadi kita tinggal klik, tinggal klik. (It's enjoyable because when we are in the digital classroom we do not need to write too much. We only 'click', and 'click'). (S1).

...lebih enak aja sih kalau di digital class, tidak bosan... (... it is more enjoyable to study in the digital classroom, I do not feel bored). (S2)

Dengan teknologi ini aku bisa belajarnya lebih enak, tidak boring juga (Through technology, I can learn more enjoyably, and it's not boring). (S3)

Besides, by using the digital classroom, they could make more exploration about the information needed since abundant access toward the information given. Like one of the students said, “... jadi lebih gampang memperoleh informasinya (it is easier to get information) (S5)". Moreover, they could also communicate or chat with other people from other countries; for example, through a video conference, they could talk to students from the Philippines; in this case, S4 revealed, "Jadi dulu kita kaya video conference kaya dengan orang luar Filipin bisa ngobrol ngobrol bareng gitu... (So, we studied through a video conference with foreign students, Phillipines; we could have some conversations one another).” Also, S5 told, “...ngga cuma dari buku doang, ngga cuma ngejelasin doang, tapi praktek langsung ngomong sama orang asing... (not only from a book, not only explain, but practice directly with foreigners)."

In addition, the class could be more conducive in comparison with the conventional classroom, especially when they did a test; S6 reported, "... kaya tadi ujian pakai computer menurut aku lebih kondusif dibanding dengan di kelas (like just now, we did the test by using a computer and for me it was more conducive than conducting it in the traditional classroom)." 
It could train them how to speak in front of people or public speaking. Moreover, they felt that it could cover all language skills, such as listening, speaking, reading, and writing. Also, it could train their creativity through writing a text in a blog. As S6 told, “... ini lebih melatih ke public speaking... tugasnya itu harus dipresentasiin setiap tugas dan tugasnya melatih kita kreativitas menulis blog tersebut. (... it gives more practice for public speaking... the assignment should be presented and it also trains us to be creative to write the blog)" Besides, the students felt positive perspectives towards the teachers' instruction by utilising the digital classroom because in the digital classroom the class seemed more interesting for each student would have their own design or web-blog with different themes and colourful in comparison with learning in the conventional/traditional classroom, they only could see the blackboard or whiteboard which was monochrome; in this case, S6 mentioned, “...mungkin lebih fun aja ngelihatnya kalau di papan tulis kan monokrom gitu kan ya, kalau disini kan setiap orang punya design atau webnya sendiri yang beda beda (...it is more fun to see it; it is because if we use whiteboard, it seems monochrome; but here in the digital classroom, everyone has their own design or the web is different from one another)."

Meanwhile, some of the students also felt that they were not used to learning by using digital classroom since it would be easier if they used books. For example, one of the students said, "...jadi aku mah karena belum terbiasa mungkin jadi lebih enak pakai kertas jadi bisa dipegang gitu...(I am not getting used to, perhaps, so I feel that using paper is more enjoyable because I can hold it...) (S4)"

Some students felt they were required to be more active and independent to learn the materials by themselves. Some students felt that the teachers lacked giving them the explanation related to the materials, thus sometimes it was found that they had less understanding about a certain material. As S4 told, "Kalau saya karena terbiasa dijelasin jadi kalau tidak dijelasin tuh... agak bingung (For me because I am used to studying through listening to teachers' explanation, so when I did not have much explanation (from teachers)... I got confused)." Moreover, the deadline or due date of the task sometimes was too close. As S5 told, "Terus ini kadang deadline terlalu mepet (Next, sometimes the dead line is too short)."

In addition, some students felt that they faced some difficulties during the presentation session since it required some preparation to convey their ideas and it could not be done spontaneous. As S6 told, “...kalau public speaking itu kan ga bisa spontan kan, harus dihapalin... (... for public speaking cannot be conducted spontaneously, it must be memorised)" and S4 also revealed, "Kadang harus latihan dulu (sometimes we must practice first)."

Moreover, the activities commonly done by the students comprised writing in their blog, doing presentations, learning through Quipper, learning through a video conference.

In addition, despite having some difficulties, the students recommended that a digital classroom was required to be implemented in other schools because it had many benefits as well as it constituted the insistence for the present era. Meanwhile, they also suggested to other students who might learn through a digital classroom to take account of the management of time when they were learning in this type of classroom as well as be pro-active whenever they found something that they did not understand; also, it was better for students to have study with the laptop to make them be accustomed to using it.

\section{Results of the Classroom Observation}

Based on the classroom observation conducted, this study reached a number of conclusions from classroom observation week 1 to week 4 as follows: the teacher gave the students a clear explanation of what to do in the beginning of the lesson. The materials were mostly focus on a descriptive text. The students presented the works that have already done beforehand. Some students did presentation voluntarily as well as the other students who did not the presentation 
ask some questions related to the materials presented by their classmates voluntarily. In this lesson, the difficulties found was related to the internet connection as well as the way the teacher monitor the class, i.e., some students were found that they played a game either through mobile phones or computers during the class.

Based on the data presentation of the study presented in three instruments above the findings could be interpreted as follows:

\section{Conformity of the lesson plan to the Curriculum 2013}

Based on the document analysis conducted most of the components of the lesson plan made by the teacher has conformity with the regulation of the ministry of education and culture, encompassing lesson identity, core competence, and basic competence, formulation of the objectives, selections in terms of resources and learning media, and learning model and method, as well as learning scenario; however, in terms of the assessment aspect, the lesson plan had less conformity to the curriculum 2013,i.e., the instrument was not included in the lesson plan and scoring scales used were not as proposed by the curriculum, that is, 00-100 scoring scale; this finding especially in terms of the aspect of assessment becoming the main issue was also corroborated by another study conducted Oktafianti (2019) who found that teachers still had some weaknesses in terms of the assessment aspect. However, overall, based on the document analysis conducted the lesson plan designed was categorised as having a good conformity, i.e. $89.6 \%$ with the curriculum 2013 and such findings were also corroborated by the results of the interview conducted in which the teacher mentioned a number of the components as well as she had good knowledge related to designing the lesson plan. According to her, a lesson plan is designed based on the regulations proposed by the Ministry of Education and Culture No. 20, $21,22,23$, and 24 as well as the latest one was about core competence and basic competence in the Regulation No. 37 year of 2018.

\section{Challenges and benefits of the implementation of the lesson plan for a digital classroom}

The challenges found during the implementation of the lesson plan encompassed the limited network connection of the internet as well as to make the lower students to catch up with other students in the learning process. Monitoring of the students behaviour was also found to be less. Also, some students were found to be not accustomed to using the learning media in the digital classroom. Some students also felt that the dead line given by the teacher is too short sometimes, and they need to have more preparation to do the task, particularly in terms of presentation. Furthermore, designing a lesson plan is not an easy matter since teachers' tasks are not only to have good administration, but they are also required to prepare media as well as to be a proficient teacher that may deliver the materials with good teaching method.

By designing the lesson plan for digital classroom in education 4.0, the teacher got a number of benefits such as the abundant resources available that could be easily searched in the internet; besides, it accommodated the necessary $21^{\text {st }}$ century skills, for instance critical thinking, communication, collaboration, and creativity. This finding related to $21^{\text {st }}$ century skills in the design of lesson plan is in line with the concept of the current education that is necessarily to address and facilitate the $21^{\text {st }}$ skills (Bialik and Fadel, 2015).

In addition, the digital classroom used had gained students' positive impression; in this case, the students perceive that it was more interesting in comparison with the learning conducted in a conventional or traditional classroom, e.g., according to the students, through a web-blog, they could made their own writing creatively based on their own design preferences; besides, through a video conference, for instance, they could have some interactions with some other students who were not only from Indonesia but also from other countries, and such condition led the students to have more understanding related to other people in relation to a number of aspects such as their culture, belief and so on; besides, according to the teacher it facilitated the students to develop their critical thinking ability, for instance, through the Generation Global platform, the students were required to know others' background so that 
they could mingle with them; this condition, according to her, eventually led them to develop their character as well, i.e., to be more emphatic to other people.

Moreover, based on the classroom observation conducted, the digital classroom had some influences particularly to the students' participation; in this case, the students were found to be voluntarily active during the presentation sessions that made use of the digital learning media. These findings of this study were also corroborated by a study conducted by (Means et al, 2013; Simin \& Sani, 2015) who found that digital classroom learning tended to surpass the traditional classroom learning. Furthermore, by implementing the lesson plan in the digital classroom in education 4.0, students had more opportunities to explore the technology to be used to practise their public speaking skill, e.g. through a video conference. Other benefits found as a result of the implementation of the lesson plan in the digital classroom was paperless, i.e. according to the students, they did not have to bring or write on books, and efficient, i.e., the students were only required to use their mobile phone or computer by touching the screen or clicking it, and according to them they could access it anywhere and anytime. This finding has conformity with a theoretical concept about the nature of a digital classroom itself which can be accessed without being tied in time and place (Munir, 2017; Hussin, 2018; belajar.kemdikbud.go.id).

\section{CONCLUSION}

This study arrived at a conclusion that the lesson plan designed by the teacher was categorised as good, i.e. it conforms $86.9 \%$ to the components to the curriculum 2013. Meanwhile, the challenges found comprised the limited network connection of the internet, more effort for the teacher to make the lower students understand the materials, students' familiarity to operating the technology, lack of monitoring of students' activities, more effort for students to do the tasks, more effort for the teacher to design it. In addition, opportunities encountered comprised the availability of the resources, accommodating the 21 st century skills, gaining the students' impressions of the materials given, and fostering students' participations as well as increasing their speaking skill, and efficiency.

This study raises some recommendations encompassed the lesson plan and the use of the digital classroom. In terms of the lesson plan, teachers are required to design it based on the regulations implemented and advocated by the ministry of education and culture and it is thus also required to be in line with the curriculum implemented, i.e. curriculum 2013. In terms of the digital classroom, the students are required to make use of it wisely, namely for the sake of education only. Also, a longitudinal study with bigger subjects or participants is suggested to obtain more comprehensive findings about designing and implementing a lesson plan with respect to a digital classroom.

\section{ACKNOWLEDGEMENTS}

The best gratitude is addressed to all participants and the teacher involving sincerely in this study and all the lecturers for their input. Without their help, this study will still remain incomplete.

\section{REFERENCES}

A copy of the regulation of the Ministry of Education and Culture No.22 year of 2016

A copy of the regulation of the Ministry of Education and Culture No. 65, 2013.

A Copy of the regulation of the Ministry of Education and Culture No. 69, 2013 
Aminah, A. N. (Ed.) (2015). Bandung kembangkan kelas digital. Retrieved October 25, 2019, from https://www.republika.co.id/berita/koran/ didaktika/15/02/04/nj8iux-bandungkembangkan-kelas-digital

Asyiah, I. N. (2015). An analysis of lesson plan based on the 2013 curriculum in teaching English. Skripsi of English Education Department of Universitas Pendidikan Indonesia, Bandung.

Bialik, M. \& Fadel, C. (2015). Skills for the $21^{\text {st }}$ century: what should students learn?. Boston: Center for Curriculum Redesign.

Brown, H. D. (2001). Teaching by principles: an interactive approach to language pedagogy. (Second edition). New York: Longman.

Daggett, B. (2014). Addressing current and future challenges in education: lessons learned from the nation's most rapidly improving and transformative schools. $22^{\text {nd }}$ Model Schools Conference.

Department of Education of Tasmania Government (2014). Good teaching: curriculum mapping and planning for learning. Australia: Department of Education of Tasmanian Government. Retrieved October 25 October 2019, from http://www.education.tas.gov.aus

Direktorat Pembinaan Sekolah Menengah Atas, Direktorat Jenderal Pendidikan Dasar dan Menengah, Kementrian Pendidikan dan Kebudayaan (2018), SMA Bahasa Inggris.

Fadhilah, M. (2014). Implementasi Kurikulum 2013 Dalam Pembelajaran SD/MI, SMP/MTS, \& SMA/MA. Yogyakarta: Ar-Ruzz Media,

Farid, M. (2014). Teachers' difficulties in lesson planning. Skripsi of English Education Department of Universitas Pendidikan Indonesia, Bandung.

Gafoor, K. A. \& Farooque, U. (2010). Ways to improve lesson planning: a student teacher perspective. Presented on International Seminar Cum Conference on Teacher Empowerment and Institutional Effectiveness, 1-3 November 2010, Maharaja Madakarinayaka FG/PG College, Chitradurga, Karnataka.

Gulten, A. Z. (2013). Am I planning well? Teachers trainees' voices on lesson planning. Procedia-Social and Behaavioral Sciences, 93, pp. 1409-1413.

Hariharasudan, A. \& Kot, S. (2018). A scoping review on digital English and education 4.0 for industry revolution 4.0. Soc.Sci, 7.

Hussin, A. A. (2018). Education 4.0 made simple: ideas for teaching. International Journal of Education \& Literacy Studies, 6, pp. 92-98.

Krathwohl, D. R. (2002). A revision of Bloom's taxonomy: an overview. Theory into Practice, 41 (4), pp. 212-218.

Kusmin, K.-L.. Analytical article information society approaches and ICT processes: industry 4.0. School of Digital Technologies, Tallin University, Estonia.

Miles, M. B. \& Huberman, A. M. (1994). Qualitative data analysis. London: Sage Publication Ltd.

Means, B. et al (2013). The effectiveness of online blended learning: a meta analysis of the empirical literature. Teachers College Record, 115, p. 47, Columbia University.

Munir (2017). Pembelajaran digital. Bandung: Alfabeta.

Nesari, A. J. \& Heidari, M. (2014). The important role of lesson plan on educational achievement of Iranian EFL teachers' attitudes. International Journal of Foreign Language Teaching \& Research, 3, 5 .

Oktafianti, T. (2019). An analysis of lesson plan made by an English teacher referring to curriculum 2013 at MTs Al-Qur'an Harsallakum Bengkulu in Academic Year 2018/2019. A thesis, IAIN Bengkulu.

Portal Rumah Belajar. (2019). Retrived October 25, 2019, from https://belajar.kemdikbud.go.id/ 
VOL. 02 NO. 02, DECEMBER 2020

Richards, J. C. (2001). Curriculum development in language teaching. Cambridge: Cambridge University Press.

Richards, J. C. \& Bohlke, D. (2011). Creating Effective Language Lessons. Cambridge: Cambridge University Press.

Simin, Ghavifekr \& Sani, Ibrahim Mohammed (2015). Effectiveness of ICT integration in Malaysian schools: a quantitative analysis. International Research Journal for Quality in Education, 2, 2015.

TEAL (2010). TEAL center fact sheet no. 8: effective lesson planning.https://lincs.ed.gov/sites/default/files/8_TEAL_Lesson_Planning.pdf

Sharoom, A. A. \& Hussin, N. (2018). Industrial revolution 4.0 and education. International Journal of Academic Research in Business and Social Sciences, 8, (9). 